\title{
How social media marketing influences consumers' purchase decision? A mediation analysis of brand awareness
}

\author{
Fajar Ardiansyah $^{1}$, Endi Sarwoko $^{2 *}$ \\ ${ }^{1}$ Department of Magister Management, Faculty of Economics and Business, Universitas \\ Kanjuruhan Malang, Malang, Indonesia \\ ${ }^{2}$ Department of Magister Management, Faculty of Economics and Business, Universitas \\ Kanjuruhan Malang, Malang, Indonesia \\ *Corresponding Author(s) Email: endiswk@unikama.ac.id
}

\section{ABSTRACT}

The important usage of social media as highly interactive platforms of communications is bound to change the way companies approach marketing. Many previous studies conclude that social media has proven to be a key factor in creating brand awareness. Thus, a higher level of awareness will affect consumers' decisions positively. However, few studies focus on the role of brand awareness as a mediation construct in affecting purchase decisions. Therefore, this study aims to explore the mediation role of brand awareness on the relationship between social media marketing and purchase decisions. The study conducted is quantitative research based on a survey approach. Purposive sampling and ordinary least square regression were used as sampling techniques and data analysis. The study revealed that social media marketing has a positive and significant influence on both brand awareness and purchase decisions. Unfortunately, this study failed to prove the direct and indirect effect of brand awareness on purchase decisions. The nature of wetsuit (sportswear) that can be categorized as a high involvement product was considered as the main reason for the insignificancy effect of brand awareness on purchase decision and the mediation role of brand awareness. In the case of high involvement products, consumers tend to be rational so that they were required more time and effort to evaluate specific product performances and characteristics.

Keywords: Social Media; Purchase Decision; Brand Awareness; Word of Mouth; Marketing
JEL Code:

M31, M37, L86

DOI:

10.31106/jema.v17i2.6916

Article History:

Received 2020/06/29

Reviewed 2020/10/11

Revised 2020/10/23

Accepted 2020/11/17

Licensed:

CC-BY 


\section{Introduction}

Social media thrived as a new era in marketing as companies can create more effective interactions with customers (Gallaugher \& Ransbotham, 2010; Kozinets et al., 2010). Social media provides an advantage for companies to reach customers or communities and to develop relationships with customers (Quinn, 2016). Social media has changed the way brands are created, distributed, and consumed to develop a brand image from producers to customers (Tsai \& Men, 2013).

Social media has changed the way consumers purchase (Chen et al., 2017). Several consumers even rely more on the information posted on their social media networks when they want to buy something Hinz et al. (2014). The trend of promotional activities through social media is a huge change in the world of marketing. Many firms used social media to spread out their promotional activities Hutter et al. (2013), improving the level of brand awareness, influence purchase decision-making, and maintain engagement with customers (Gallaugher \& Ransbotham, 2010; Bernstein et al., 2013; Hinz et al., 2014; Godey et al., 2016). Ahmad et al. (2018) added that many firms decide to spend more of their promotional budget on social media as the cost of social ads is relatively low in comparison to traditional methods.

Many previous studies conclude that social media has proven to be a key factor in creating brand awareness (Goodrich \& de Mooij, 2014; Prasad et al., 2017; Enyioko \& Okwandu, 2019). Thus, the higher level of awareness and the positive reviews of social media user interactions will affect consumers' decisions positively (Malik et al., 2013; Yogesh \& Yesha, 2014). However, few studies focus on the role of brand awareness as a mediation construct in affecting purchase decisions. An initial indication on the mediation role of brand awareness is proposed based on Shabbir et al. (2010) study on the role of marketing campaigns on consumer purchase intention which has found that the relationship exists when there is brand awareness that plays as mediation. Macdonald \& Sharp (2000) and Huang \& Sarigöllü (2014) added that brand awareness will affect consumer decision making as many consumers use it as the basis for evaluation of purchase decisions. Therefore, this study aims to explore the mediation role of brand awareness on the relationship between social media marketing and purchase decisions. This study was conducted in one of the biggest and experienced (more than 20 years) wetsuit (sportswear) manufacturer on the island of Bali which relies on social media platforms to market and sell its products. 


\section{Literature Review}

\section{Social Media Marketing}

Yong \& Hassan (2019) defined social media marketing as a process that allows individuals to promote their product or services through online social channels and tap into a much larger community. The usage of social media marketing ranged from being not only in individual scope but also affecting the industry as a whole. Therefore, social media marketing also can be defined as a firm's marketing efforts to encourage (potential) customers' interest toward the brand by using various internet marketing channels such as blogs, websites, social media, and others (Magasic, 2016). Jin et al., (2019) stated that social media marketing is built upon the idea of interaction between the brand and its consumers, to listen to their valuable feedback so they can improve the experience. They added that the usage of social media platforms (such as Instagram) as one of the marketing tools can enable them to effectively and efficiently communicate the benefit of brands.

\section{The Relationship of Social Media Marketing, Brand Awareness, and Purchase Decision}

Many previous studies show that social media marketing activities had a positive influence on the level of brand awareness as the nature of social media users easily share the content with their connected friends (Bruhn et al., 2012; Hutter et al., 2013; Barreda et al., 2015; Bilgin, 2018; Seo \& Park, 2018). It also means that the more frequent the usage of social media, the higher level of brand awareness will be. Other findings suggest that there is an aftereffect of social media marketing activities on brand quality, brand equity, and customer value (Stojanovic et al., 2018). Therefore, Barreda et al. (2015) ended the argument by saying that social media activities have proved important in strengthening brand awareness.

$\mathrm{H}_{1}$ : $\quad$ Social media marketing has a positive effect on brand awareness.

The presence of social media is an alternative media to establish communication with customers. Social media has become a platform where consumers interact with a brand (Tsai $\&$ Men, 2013), the interaction has a significant impact on consumer purchase decisions (Elwalda \& Lu, 2016). The use of social media will help to increase purchase decisions (Goodrich \& de Mooij, 2014), as social media will increase active user participation and will influence the behavior of consumers (Seo \& Park, 2018), by changing the consumer decisionmaking process in purchasing (Hudson \& Thal, 2013). Communication on social media will 
increase purchase intention (Jalilvand \& Samiei, 2012) which leads to purchase decisions (Prasad et al., 2017).

$\mathrm{H}_{2}$ : $\quad$ Social media marketing has a positive effect on purchase decisions.

\section{The Relationship of Brand Awareness and Purchase Decision}

Several previous studies that focus on brand awareness show that there is a positive relationship between brand awareness and purchase decisions (Khuong \& Tram, 2015; Novansa \& Ali, 2017). Jung \& Seock (2016), Kumar \& Gupta (2016), and Siali et al. (2019) stated that raising the level of brand awareness will enhance the likelihood to consider the brands when making purchase decisions. In a simple meaning, the higher the level of awareness on a specific brand, the higher the possibility of those brands to be purchase.

$\mathrm{H}_{3}$ : Brand awareness has a positive effect on purchase decisions.

\section{The Mediation Role of Brand Awareness}

Few studies focus on the role of brand awareness as a mediation construct in affecting purchase decisions. An initial indication on the mediation role of brand awareness is based on Shabbir et al. (2010) study on the role of marketing campaigns on consumer purchase intention which has found that the relationship exists when there is brand awareness that plays as mediation. In line with the conclusion by Shabbir et al. (2010), Sharifi (2014) also confirmed the mediating role of brand awareness in affecting the relationship between the trilogy of emotion and future purchase intentions. Macdonald \& Sharp (2000) and Huang \& Sarigöllü (2014) added that brand awareness will affect consumer decision making as many consumers use it as the basis for evaluation of purchase decisions.

$\mathrm{H}_{4}$ : The effect of social media marketing on purchase decisions is affected by brand awareness.

\section{Methods}

The study can be classified as explanatory research which used a survey (questionnaire) to collect data and test four proposed hypotheses (Figure 1). Purposive sampling and ordinary least square regression were used as sampling techniques and data analysis. This study was designed to focus on individuals who can be classified as social media active users (followers of the specific brand) and have the experience to buy specific brands/products on one of social media platforms. This study was conducted in one of the biggest and experienced (more than 20 years) wetsuit (sportswear) manufacturer on the island of Bali (namely SeaGods) which relies on social media platforms to market and sell its products. Instagram 
was chosen as social media object not only because of its uniqueness and easy access feature (Din et al., 2018) but also is considered as the most effective marketing tool concerning young aged consumers (Djafarova \& Bowes, 2020). A questionnaire with five-point Likert scales (ranged from $1=$ strongly disagree to $5=$ strongly agree) that consists of several items was distributed to 300 target respondents. After selecting all collected data by its sample criteria, the total respondent that involved and classified to be processed in this study is 100 respondents.

Figure 1. Research Framework

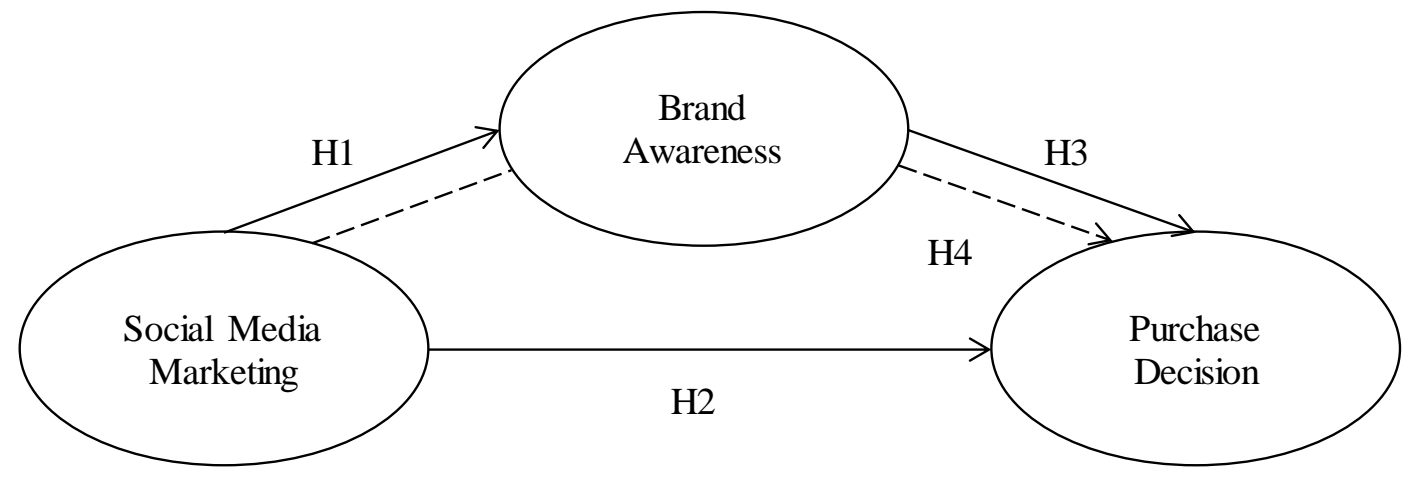

Table 1. Questionnaire Items

\begin{tabular}{|c|c|c|c|}
\hline Variable & Code & Item & Reference \\
\hline \multirow{5}{*}{$\begin{array}{l}\text { Social Media } \\
\text { Marketing } \\
(\text { SMM) }\end{array}$} & SMM1 & $\begin{array}{l}\text { I often interact with other users when I'm accessing } \\
\text { SeaGod 's Instagram. }\end{array}$ & \multirow{5}{*}{$\begin{array}{l}\text { Kim \& Ko, } \\
\quad(2012)\end{array}$} \\
\hline & SMM2 & $\begin{array}{l}\text { I would like to share the information about SeaGods } \\
\text { with my friends. }\end{array}$ & \\
\hline & SMM3 & SeaGods Instagram is very trendy. & \\
\hline & SMM4 & $\begin{array}{l}\text { The content that was posted on SeaGods Instagram } \\
\text { was very entertaining. }\end{array}$ & \\
\hline & SMM5 & $\begin{array}{l}\text { SeaGods Instagram offers a customized information } \\
\text { search. }\end{array}$ & \\
\hline \multirow{2}{*}{$\begin{array}{l}\text { Brand } \\
\text { Awareness } \\
\text { (BA) }\end{array}$} & BA1 & $\begin{array}{l}\text { When I think of swimsuit sportswear, SeaGods } \\
\text { comes to my mind. }\end{array}$ & \multirow{2}{*}{$\begin{array}{l}\text { Hutter et al. } \\
\qquad(2013)\end{array}$} \\
\hline & BA2 & $\begin{array}{l}\text { I can distinguish the difference between SeaGods } \\
\text { model. }\end{array}$ & \\
\hline \multirow{3}{*}{$\begin{array}{l}\text { Purchase } \\
\text { Decision (PD) }\end{array}$} & PD1 & $\begin{array}{l}\text { I use Instagram to gain more information about a } \\
\text { specific brand or product. }\end{array}$ & \multirow{3}{*}{$\begin{array}{l}\text { Prasad et al. } \\
\qquad \text { (2017) }\end{array}$} \\
\hline & PD2 & $\begin{array}{l}\text { It is important to me that I make the right choice of } \\
\text { the product based on the information that I have. }\end{array}$ & \\
\hline & PD3 & $\begin{array}{l}\text { In making my selection of the product, the best } \\
\text { alternative is chosen as the outcome of my choice. }\end{array}$ & \\
\hline
\end{tabular}


In this study, social media marketing was measure by Kim et al. (2009) dimension which consists of entertainment, interaction, trend, customization, and word of mouth. While brand awareness was measure by Hutter et al., (2013) dimension that consists of easy to remember and easy to distinguish, purchase decisions were developed by using Prasad et al. (2017) dimension. The details of variable measurement can be seen in Table 1. Thus, to continue to analyze the proposed hypotheses, the validity and reliability measurements of research instruments need to be done. The results of the validity and reliability testing in Table 2 show that all instruments used in this study were valid and reliable.

Table 2. Validity and Reliability Result

\begin{tabular}{cccccc}
\hline Variable/Item & $\begin{array}{c}\text { Pearson } \\
\text { Correlation }\end{array}$ & Criteria & $\begin{array}{c}\text { Cronbach's } \\
\text { Alpha }\end{array}$ & Criteria & Decision \\
\hline SMM & 0.836 & $>0.196$ & 0.886 & $>0.600$ & Reliable \\
SMM1 & 0.795 & $>0.196$ & & Valid \\
SMM2 & 0.864 & $>0.196$ & & & Valid \\
SMM3 & 0.830 & $>0.196$ & & & Valid \\
SMM4 & 0.820 & $>0.196$ & & & Valid \\
SMM5 & & & 0.600 & Valid \\
BA & 0.924 & $>0.196$ & & & Reliable \\
BA1 & 0.920 & $>0.196$ & & & Valid \\
BA2 & & & 0.816 & & Valid \\
PD & 0.822 & $>0.196$ & & & Reliable \\
PD1 & 0.871 & $>0.196$ & & & Valid \\
PD2 & 0.874 & $>0.196$ & & Valid \\
PD3 & & & & \\
\hline
\end{tabular}

\section{Result and Discussion}

The results of testing the causal relationship model between social media marketing, brand awareness, and purchase decision can be seen in Table 3. This study was able to confirm the proposed hypotheses $\mathrm{H}_{1}$ and $\mathrm{H}_{2}$ which stated that there are a positive relationship and significant effect of social media marketing on brand awareness, and social media marketing on purchase decision as the value of t-tested was 17.086 and 3.860 (which is higher than the value of t-statistics 1.984) with significant value of 0.000 (which is lower than significances criteria of 0.05). It means that the more frequent the social media marketing activities held by companies, the higher the level of brand awareness and the possibility to 
purchase will be. The result of this study proved the conclusion of Hutter et al. (2013), Tsimonis \& Dimitriadis (2014), Ismail (2017), and Barreda et al. (2015) that stated the use of social media has proven significantly can enhance brand awareness, increasing the number of sales, and influences the purchase decision-making.

Table 3. Hypotheses Testing

\begin{tabular}{lccccc}
\hline Hypotheses & t-Value & $\begin{array}{c}\text { t-Table } \\
\text { Criteria }\end{array}$ & Sig. & $\begin{array}{c}\text { Sig. } \\
\text { Criteria }\end{array}$ & Decision \\
\hline $\mathrm{H}_{1} \mathrm{SMM}->$ BA & 17.086 & $>1.984$ & 0.000 & $<0.005$ & Accepted \\
$\mathrm{H}_{2} \mathrm{SMM}$-> PD & 3.860 & $>1.984$ & 0.000 & $<0.005$ & Accepted \\
$\mathrm{H}_{3} \mathrm{BA}->\mathrm{PD}$ & 1.709 & $>1.984$ & 0.090 & $<0.005$ & Rejected \\
\hline
\end{tabular}

Unlike previous studies by Novansa \& Ali (2017), Hutter et al. (2013), Jung \& Seock (2016), Kumar \& Gupta (2016), and Siali et al. (2019), this study failed to prove the relationship between brand awareness and purchase decision $\left(\mathrm{H}_{3}\right)$ as the value of t-tested was 1.709 (which is lower than the value of t-statistics 1.984) with significant value of 0.090 (which is higher than significances criteria of 0.05). In the beginning, SeaGods social media (Instagram) was built upon the idea to massively introduce the SeaGods brand to a broader market so consumers will remember the SeaGods brand and be able to distinguish the different types of SeaGods products. Barreda et al. (2015) added that the use of social media can help brand generates word of mouth organically as social media itself that considered as online information-sharing activities, circulating information, is used to get to know products, brands, and services (Di Pietro et al., 2012). Therefore, it can be concluded that due to the initial purpose of SeaGods Instagram that more focus on the activity that can increase the level awareness of SeaGods brand, it is understandable that there is no significant relationship between brand awareness and purchase decision.

Table 4. The Mediation Role of Brand Awareness

\begin{tabular}{lccccc}
\hline Hypotheses & Effect & BootSE & BootLLCI & BootULCI & Decision \\
\hline $\mathrm{H}_{4}$ SMM -> BA -> PD & 0.122 & 0.079 & -0.032 & 0.277 & Rejected \\
\hline
\end{tabular}

The result of this study also was not able to confirm $\mathrm{H}_{4}$ which stated that the effect of social media marketing on purchase decisions is affected by brand awareness. Hayes (2018) stated that when the upper and lower bounds of the $95 \%$ confidence interval do not contain zero, it can be concluded that the indirect effect was existed or significant. Table 4 shows that there is no significant proof of the mediation role of brand awareness on the relationship 
between social media marketing and purchase decision as zero is a possible value between a negative number of BootLLCI (-0.032) and a positive number of BootULCI (0.277). The swimsuit is a type of sportswear and belongs to the category of high-involvement products (Radder \& Huang, 2008). High involvement products will involve the subjective feelings of the customer, not only consumers will pay special attention, comparing product characteristics with several other brands before making a purchase decision (Yousaf \& Malik, 2013), they also will evaluate the image of a product (Oh \& Fiorito, 2002). This finding revealed that there is no guarantee that when consumers feel familiar with some brand or product, the possibility to made purchase decisions toward those specific brands or products will increasing automatically. The level of involvement plays a significant role in affecting consumers' decision to purchase (Radder \& Huang, 2008). In the case of high involvement products, consumers tend to be rational so that they were required more time and effort to evaluate specific product performances and characteristics.

\section{Conclusion and Suggestion}

This study aims to explore the mediation role of brand awareness on the relationship between social media marketing and purchase decisions. The study revealed that social media marketing has a positive and significant influence on both brand awareness and purchase decision which means that the more frequent the social media marketing activities held by companies, the higher the level of brand awareness and the possibility to purchase will be. Unfortunately, this study failed to prove the direct and indirect effect of brand awareness on purchase decisions. The nature of wetsuit (sportswear) that can be categorized as a high involvement product was considered as the main reason for the insignificancy effect of brand awareness on purchase decision and the mediation role of brand awareness. In the case of high involvement products, consumers tend to be rational so that they were required more time and effort to evaluate specific product performances and characteristics. Also, the initial purpose of SeaGods Instagram that was built for brand awareness purpose only considered as another factor that caused the insignificant relationship between brand awareness and purchase decision. This study only focused on the high involvement product category which is a swimsuit (sportswear), further analysis is needed by comparing the various level of involvement to gain an in-depth perspective. Moreover, the dimension of brand equity used in this study was limited only to brand awareness. Therefore, further study should be done by including a brand image, brand love, and brand loyalty as a developed model. 


\section{References}

Ahmad, S. Z., Ahmad, N., \& Abu Bakar, A. R. (2018). Reflections of entrepreneurs of small and medium-sized enterprises concerning the adoption of social media and its impact on performance outcomes: Evidence from the UAE. Telematics and Informatics, 35(1), 617. https://doi.org/10.1016/j.tele.2017.09.006

Barreda, A. A., Bilgihan, A., Nusair, K., \& Okumus, F. (2015). Generating brand awareness in online social networks. Computers in Human Behavior, 50, 600-609. https://doi.org/10.1016/j.chb.2015.03.023

Bernstein, M. S., Bakshy, E., Burke, M., \& Karrer, B. (2013). Quantifying the invisible audience in social networks. In Proceedings of the SIGCHI Conference on Human Factors in Computing Systems - CHI'13 (p. 21). New York, New York, USA: ACM Press. https://doi.org/10.1145/2470654.2470658

Bilgin, Y. (2018). The effect of social media marketing activities on brand awareness, brand image and brand loyalty. Business \& Management Studies: An International Journal, 6(1), 128-148. https://doi.org/10.15295/bmij.v6i1.229

Bruhn, M., Schoenmueller, V., \& Schäfer, D. B. (2012). Are social media replacing traditional media in terms of brand equity creation? Management Research Review, 35(9), 770-790. https://doi.org/10.1108/01409171211255948

Chen, A., Lu, Y., \& Wang, B. (2017). Customers' purchase decision-making process in social commerce: A social learning perspective. International Journal of Information Management, 37(6), 627-638. https://doi.org/10.1016/j.ijinfomgt.2017.05.001

Di Pietro, L., Di Virgilio, F., \& Pantano, E. (2012). Social network for the choice of tourist destination: attitude and behavioural intention. Journal of Hospitality and Tourism Technology, 3(1), 60-76. https://doi.org/10.1108/17579881211206543

Din, S. M., Ramli, R., \& Bakar, A. A. (2018). A review on trust factors affecting purchase Intention on Instagram. In 2018 IEEE Conference on Application, Information and $\begin{array}{llll}\text { Network } & \text { Security } & \text { (AINS) } & \text { (pp. }\end{array}$ https://doi.org/10.1109/AINS.2018.8631501

Djafarova, E., \& Bowes, T. (2020). 'Instagram made Me buy it': Generation Z impulse purchases in fashion industry. Journal of Retailing and Consumer Services, 102345. https://doi.org/10.1016/j.jretconser.2020.102345

Elwalda, A., \& Lu, K. (2016). The impact of online customer reviews (OCRs) on customers' purchase decisions: An exploration of the main dimensions of OCRs. Journal of 
https://doi.org/10.1362/147539216X14594362873695

Enyioko, N. C., \& Okwandu, G. A. (2019). Effect of social media marketing on the conversion rate of deposit money banks in Nigeria. JEMA: Jurnal Ilmiah Bidang Akuntansi Dan Manajemen, 16(1), 1. https://doi.org/10.31106/jema.v16i1.2141

Gallaugher, J., \& Ransbotham, S. (2010). Social media and customer dialog management at Starbucks. MIS Quarterly Executive, 9(4).

Godey, B., Manthiou, A., Pederzoli, D., Rokka, J., Aiello, G., Donvito, R., \& Singh, R. (2016). Social media marketing efforts of luxury brands: Influence on brand equity and consumer behavior. Journal of Business Research, 69(12), 5833-5841. https://doi.org/10.1016/j.jbusres.2016.04.181

Goodrich, K., \& de Mooij, M. (2014). How 'social' are social media? A cross-cultural comparison of online and offline purchase decision influences. Journal of Marketing Communications, 20(1-2), 103-116. https://doi.org/10.1080/13527266.2013.797773

Hayes, A. F. (2018). Partial, conditional, and moderated moderated mediation: Quantification, inference, and interpretation. Communication Monographs, 85(1), 4-40. https://doi.org/10.1080/03637751.2017.1352100

Hinz, O., Schulze, C., \& Takac, C. (2014). New product adoption in social networks: Why direction matters. Journal of Business Research, 67(1), 2836-2844. https://doi.org/10.1016/j.jbusres.2012.07.005

Huang, R., \& Sarigöllü, E. (2014). How brand awareness relates to market outcome, brand equity, and the marketing mix (pp. 113-132). https://doi.org/10.1007/978-1-4939-02774_8

Hudson, S., \& Thal, K. (2013). The impact of social media on the consumer decision process: Implications for tourism marketing. Journal of Travel \& Tourism Marketing, 30(1-2), 156-160. https://doi.org/10.1080/10548408.2013.751276

Hutter, K., Hautz, J., Dennhardt, S., \& Füller, J. (2013). The impact of user interactions in social media on brand awareness and purchase intention: the case of MINI on Facebook. Journal of Product \& Brand Management, 22(5/6), 342-351. https://doi.org/10.1108/JPBM-05-2013-0299

Ismail, A. R. (2017). The influence of perceived social media marketing activities on brand loyalty. Asia Pacific Journal of Marketing and Logistics, 29(1), 129-144. https://doi.org/10.1108/APJML-10-2015-0154

Jalilvand, M. R., \& Samiei, N. (2012). The effect of electronic word of mouth on brand 
image and purchase intention. Marketing Intelligence \& Planning, 30(4), 460-476. https://doi.org/10.1108/02634501211231946

Jin, S. V., Muqaddam, A., \& Ryu, E. (2019). Instafamous and social media influencer marketing. Marketing Intelligence \& Planning, 37(5), 567-579. https://doi.org/10.1108/MIP-09-2018-0375

Jung, N. Y., \& Seock, Y.-K. (2016). The impact of corporate reputation on brand attitude and purchase intention. Fashion and Textiles, 3(1), 20. https://doi.org/10.1186/s40691-0160072-y

Khuong, M. N., \& Tram, V. N. B. (2015). The effects of emotional marketing on consumer product perception, brand awareness and purchase decision - A Study in Ho Chi Minh City, Vietnam. Journal of Economics, Business and Management, 3(5), 524-530. https://doi.org/10.7763/JOEBM.2015.V3.240

Kim, A. J., \& Ko, E. (2012). Do social media marketing activities enhance customer equity? An empirical study of luxury fashion brand. Journal of Business Research, 65(10), 1480-1486. https://doi.org/10.1016/j.jbusres.2011.10.014

Kim, S., Haley, E., \& Koo, G.-Y. (2009). Comparison of the paths from consumer involvement types to ad responses between corporate advertising and product advertising. Journal of Advertising, 38(3), 67-80. https://doi.org/10.2753/JOA00913367380305

Kozinets, R. V., De Valck, K., Wojnicki, A. C., \& Wilner, S. J. S. (2010). Networked narratives: understanding word-of-mouth marketing in online communities. Journal of Marketing, 74(2), 71-89. https://doi.org/10.1509/jm.74.2.71

Kumar, V., \& Gupta, S. (2016). Conceptualizing the evolution and future of advertising. Journal of Advertising, 45(3), 302-317. https://doi.org/10.1080/00913367.2016.1199335

Macdonald, E. K., \& Sharp, B. M. (2000). Brand awareness effects on consumer decision making for a common, repeat purchase product: A replication. Journal of Business Research, 48(1), 5-15. https://doi.org/10.1016/S0148-2963(98)00070-8

Magasic, M. (2016). The 'Selfie Gaze' and 'Social Media Pilgrimage': Two frames for conceptualising the experience of social media using tourists. In Information and Communication Technologies in Tourism 2016 (pp. 173-182). Cham: Springer International Publishing. https://doi.org/10.1007/978-3-319-28231-2_13

Malik, M. E., Ghafoor, M. M., Iqbal, H. K., Ali, Q., Hunbal, H., Noman, M., \& Ahmad, B. (2013). Impact of brand image and advertisement on consumer buying behavior. World Applied Sciences

Journal,

$23(1)$

$117-122$. 
How social media marketing influences consumers' purchase decision? A mediation analysis of brand awareness by Fajar Ardiansyah, Endi Sarwoko

https://doi.org/10.5829/idosi.wasj.2013.23.01.824

Novansa, H., \& Ali, H. (2017). Purchase decision model: Analysis of brand image, brand awareness and price (Case study SMECO Indonesia SME products). Saudi Journal of Humanities and Social Sciences, 2(8), 621-632.

Oh, J., \& Fiorito, S. S. (2002). Korean women's clothing brand loyalty. Journal of Fashion Marketing and Management: An International Journal, 6(3), 206-222. https://doi.org/10.1108/13612020210441328

Prasad, S., Gupta, I. C., \& Totala, N. K. (2017). Social media usage, electronic word of mouth and purchase-decision involvement. Asia-Pacific Journal of Business Administration, 9(2), 134-145. https://doi.org/10.1108/APJBA-06-2016-0063

Quinn, K. (2016). Why We share: A uses and gratifications approach to privacy regulation in social media use. Journal of Broadcasting \& Electronic Media, 60(1), 61-86. https://doi.org/10.1080/08838151.2015.1127245

Radder, L., \& Huang, W. (2008). High-involvement and low-involvement products. Journal of Fashion Marketing and Management: An International Journal, 12(2), 232-243. https://doi.org/10.1108/13612020810874908

Seo, E.-J., \& Park, J.-W. (2018). A study on the effects of social media marketing activities on brand equity and customer response in the airline industry. Journal of Air Transport Management, 66, 36-41. https://doi.org/10.1016/j.jairtraman.2017.09.014

Shabbir, S., Kaufmann, H. R., Ahmad, I., \& Qureshi, I. M. (2010). Cause related marketing campaigns and consumer purchase intentions: The mediating role of brand awareness and corporate image. African Journal of Business Management, 4(6), 1229-1235. https://doi.org/https://doi.org/10.5897/AJBM.9000129

Sharifi, S. S. (2014). Impacts of the trilogy of emotion on future purchase intentions in products of high involvement under the mediating role of brand awareness. European Business Review, 26(1), 43-63. https://doi.org/10.1108/EBR-12-2012-0072

Siali, F., Jiayi, P., Shakur, M. M. A., \& Ya'kob, S. A. (2019). Relationship between brand equity and consumer purchase decision. International Journal of Service Management and Sustainability, 1(1), 58-75.

Stojanovic, I., Andreu, L., \& Curras-Perez, R. (2018). Effects of the intensity of use of social media on brand equity. European Journal of Management and Business Economics, 27(1), 83-100. https://doi.org/10.1108/EJMBE-11-2017-0049

Tsai, W.-H. S., \& Men, L. R. (2013). Motivations and antecedents of consumer engagement with brand pages on social networking sites. Journal of Interactive Advertising, 13(2), 
76-87. https://doi.org/10.1080/15252019.2013.826549

Tsimonis, G., \& Dimitriadis, S. (2014). Brand strategies in social media. Marketing Intelligence \& Planning, 32(3), 328-344. https://doi.org/10.1108/MIP-04-2013-0056

Yogesh, F., \& Yesha, M. (2014). Effect of social media on purchase decision. Pacific Business Review International, 6(11), 45-51.

Yong, K., \& Hassan, R. A. (2019). The relationships between social media marketing and entrepreneurial success: A conceptual study on homestay business in Sabah, Malaysia. Review of Integrative Business and Economics Research, 8, 25-33.

Yousaf, S., \& Malik, M. S. (2013). Evaluating the influences of religiosity and product involvement level on the consumers. Journal of Islamic Marketing, 4(2), 163-186. https://doi.org/10.1108/17590831311329296 